\title{
Physio-biochemical Responses of In Vitro Cooking Banana Musa paradisiaca cv Lang towards Polyethylene Glycol (PEG)- Induced Drought Stress
}

\author{
Sharifah Zafierah Syed Badrulzaman, Nurhana Nadia Ramlan, Munirah \\ Adibah Kamarul Zaman, Azzreena Mohamad Azzeme* \\ Department of Biochemistry, Faculty of Biotechnology and Biomolecular Sciences, \\ Universiti Putra Malaysia, 43400 UPM Serdang, Selangor, Malaysia
}

Abstract Musa paradisiaca cv Lang belongs to the cooking banana group, and it has high potential to be used in banana chips production. Like other cultivars, M. paradisiaca cv Lang is susceptible to drought, which could affect banana growth and productivity. Therefore, in this study we aimed to determine the physiological and biochemical changes of in vitro Lang banana plantlets grown under drought stress. To achieve the objective, polyethylene glycol (PEG) was added into the culture media to induce drought condition. The physio-biochemical data were captured by determining root and leaves number, root length, total chlorophyll content, total protein content, and antioxidant enzymes activities. Overall, decrement of roots length and chlorophyll (Chl) content was displayed by the plantlets exposed to $1 \%, 2 \%, 3 \%, 4 \%$, and $5 \%$ $(\mathrm{w} / \mathrm{v})$ of PEG after three weeks of exposure. However, the proline content, total soluble protein content, and antioxidant capacity in leaves and roots were varied in response to different concentrations of PEG. Plantlets supplemented with $2 \%(\mathrm{w} / \mathrm{v})$ of PEG recorded the highest proline content in leaf $(12.66 \pm 0.38 \mu \mathrm{mole} / \mathrm{g} \mathrm{FW})$ while the total soluble protein content was recorded the highest in roots of $5 \%(\mathrm{w} / \mathrm{v})$ of PEG-treated plantlets $(30.65 \pm 1.07 \mathrm{mg} / \mathrm{g} \mathrm{FW})$. The highest catalase (CAT) and guaiacol peroxidase (POD) activities were found in the leaf of $1 \%(w / v)(10.69 \pm 5.06$ $\mu \mathrm{mol} / \mathrm{min} / \mathrm{mg}$ protein) and $4 \%(\mathrm{w} / \mathrm{v})(0.079 \pm 0.03 \mu \mathrm{mol} / \mathrm{min} / \mathrm{mg}$ protein) of PEG- treated plantlets. Meanwhile, the highest ascorbate peroxidase (APX) activity was found in the roots of $3 \%(\mathrm{w} / \mathrm{v})$ of PEG-treated plantlets $(16.69 \pm 0.5 \mu \mathrm{mol} / \mathrm{min} / \mathrm{mg}$ protein). Therefore, these data show the capability of Lang banana to develop physio-biochemical mechanisms in response to different levels of drought stress, in which these data can be used in the future to develop drought tolerant Lang banana.

Keywords: Antioxidant enzyme activity; chlorophyll content; drought stress; Musa paradisiaca cv Lang;

*For correspondence: azzreena@upm.edu.my

Received: 17 July 2021 Accepted: 22 Nov 2021

(C) Copyright Badrulzaman et al. This article is distributed under the terms of the Creative Commons Attribution License, which permits unrestricted use and redistribution provided that the original author and source are credited. polyethylene glycol.

\section{Introduction}

Climate change has prolonged hot temperature period and reduced rainfall rate and freshwater availability. These impacts lead to the occurrence of drought stress or dehydration that negatively affects growth and productivity of many food crops including banana [1,2]. Banana requires different water amount in different conditions. For instance, M. paradisiaca cv. Domino-Harton requires sufficient daily water uptakes, which are about $26 \mathrm{~L}$ in sunny weather, $17 \mathrm{~L}$ in semi-cloudy weather, and $10 \mathrm{~L}$ in cloudy weather [3]. Lack of water uptake by banana especially under sunny or drought condition can overheat plant cells and tissues, decrease transpiration rate, and reduce photosynthetic rate [3,4]. These physiological changes lead to reduction of banana yield and fruit quality [5]. Symptoms like wilting and drying of leaves, reduced bunch and finger size, stunted growth, strangled birth, snapping of weak 
pseudo-stem, and formation of leaf petiole rosette may occur under severe water stress in banana. Meanwhile, water withholding imposed at flowering stage of banana for one month showed a reduction in the bunch weight, fruit length, and circumference in cultivars 'Robusta', 'Karpuravalli', and 'Rasthali' [6].

There are two types of bananas: edible banana and cooking banana. Musa paradisiaca cv. Lang or known as Lang or Helang banana amongst Malaysian belongs to cooking banana group. This cultivar has similar fruit shape with Musa paradisiaca cv. Tanduk but Lang banana produces more fruits with smaller size compared to Tanduk banana [7]. In Malaysia, Lang banana fruits have been used to produce banana chips and fritters. This cultivar may also offer health benefits to humans as most of the banana cultivars have been reported to contain high antioxidant compounds [8].

Addition of PEG in the nutrient media can block absorption of water by root system, therefore mimicking drought stress and decreasing photosynthesis rate [4]. Heretofore, PEG-induced drought stress has been successfully studied in many plants such as soybean [10], rice [4], chickpea [11], banana [9], tomato [12], peanut [13], and barley [14]. The level of drought stress induction however depends on concentration of PEG and plant species. The reduction of photosynthesis rate under PEG treatment could also be associated with chlorophyll degradation [13]. There are two chlorophyll pigments that play vital roles in capturing energy from sunlight and running photosynthesis. Chl $a$ is the main chlorophyll in photosynthesis while $\mathrm{Chl} b$ role is to support $\mathrm{Chl}$ a by supplying more light energy [15]. Under drought condition, photolysis of water could be interfered, therefore impairment of photosystem II (PSII) occurs and resulting $\mathrm{Chl}$ a reduction [16].

Previous study conducted on Grand Nain cultivar, the banana that belongs to dessert banana group showed the reduction of root length, root number, and leaf number in response to PEG [9]. The decrement of vegetative growth is due to cellular dehydration suffered by the plants. To lessen the injuries, activation of antioxidant capacity has been reported in many plant species including dessert banana, but none has been recorded on Lang banana, the cooking cultivar. Activation of enzymatic and non-enzymatic antioxidants is generally occurred to protect plant cells from reactive oxygen species (ROS) [17]. Enzymatic antioxidants like catalase, peroxidase, ascorbate peroxidase, and superoxide dismutase are activated in stressed plants not only to reduce ROS but also malondialdehyde content $[5,18]$. Similar function has also been observed for non-enzymatic antioxidants such as ascorbic acid, tocopherol, and carotenoids [19]. Apart from that, the accumulation of proline in drought-stressed plants is important to adjust cell osmotic and protect cell components as proline can maintain cell turgor during water deficit, and therefore allowing cell enlargement and plant growth [20]. However, the physiological and biochemical changes rely on plant species and cultivar, including banana, which none of the studies has been reported on Lang cultivar. Therefore, in this study we aimed to determine physiological and biochemical responses of in vitro Lang banana plantlets when the plants were treated with different concentrations of PEG.

\section{Materials and methods}

\section{Plant materials}

In vitro plantlets of Musa paradisiaca cv. Lang were obtained from Plant Biochemistry and Biotechnology Laboratory, Department of Biochemistry, Faculty of Biotechnology and Biomolecular Sciences, Universiti Putra Malaysia, Malaysia. The in vitro plantlets were established from 4 months old of Lang banana sword suckers. The pointed stem and leaves of sword suckers were cut until basal part reached $15 \mathrm{~cm}$ length prior to surface sterilization. The sterilized meristem block tissues obtained were longitudinal cut into half and cultured on full-strength of Murashigae and Skoog (MS) basal media [21] containing Gamborg B5 vitamin [22] and $5 \mathrm{mg} / \mathrm{L}$ Kinetin (MS5K) at $24 \pm 2{ }^{\circ} \mathrm{C}$ and photoperiod $16 / 8$ hour for day and night using Tubular 8 (T8) day light light-emitting diode (LED) 1080 lumen. The plantlets produced were then cut and cultured on new MS5K media under the same growth condition. After 3 weeks of culture, the plantlets were transferred onto full-strength MS basal media without plant growth regulators (PGRs), named as MSO for a week prior to PEG treatment.

\section{PEG treatment}

The roots of banana plantlets were cut into $2 \mathrm{~cm}$, and the plantlets were grown in full-strength of liquid MS basal media containing Gamborg B5 vitamin and different concentrations of PEG $8000(1 \%, 2 \%$, $3 \%, 4 \%$ and $5 \%(\mathrm{w} / \mathrm{v}))$ to induce drought stress [9]. The growth of banana plantlets was monitored by recording the number of leaves, number of roots, and length of roots after 3 weeks of PEG treatment. 
The control treatment was conducted by growing the plantlets in full-strength of liquid MSO containing Gamborg B5 vitamin. Each treatment consisted of five replicates.

\section{Determination of total chlorophyll content in leaf}

Frozen leaf sample with weight of $0.1 \mathrm{~g}$ was ground using pre-chilled mortar and pestle in $2 \mathrm{~mL}$ of $80 \%$ $(\mathrm{v} / \mathrm{v})$ acetone. Calcium carbonate $(0.1 \mathrm{~g})$ was then added into the crude extract, and the mixture was further homogenized. The extract was filtered using Whatman paper No.1 and the excess sample was washed with acetone until it became colourless. The $80 \%(\mathrm{v} / \mathrm{v})$ acetone was added into the mixture until it reached $4 \mathrm{~mL}$. The absorbance was measured at $645 \mathrm{~nm}(\mathrm{Chl} b)$ and $663 \mathrm{~nm}(\mathrm{Chl} a)$. The reading was taken in triplicate. The total chlorophyll content was expressed as milligram per gram fresh weight $(\mathrm{mg} / \mathrm{g}$ $\mathrm{FW}$ ). The content of $\mathrm{Chl} a, \mathrm{Chl} b$, and total $\mathrm{Chl}$ were calculated based on equation 1, 2, and 3 below:

$$
\begin{aligned}
& \text { Chl } a(\mathrm{mg} / \mathrm{g})=\frac{12.3 A_{663}-0.86 A_{645} \times V}{a \times 1000 \times W} \\
& \text { Chl } b(\mathrm{mg} / \mathrm{g})=\frac{19.3 A_{645}-3.6 A_{663} \times V}{a \times 1000 \times W}
\end{aligned}
$$

Total $\mathrm{Chl}=$ Total Chl $a(\mathrm{mg} / \mathrm{g})+$ Total $\mathrm{Chl} b(\mathrm{mg} / \mathrm{g})$

Where $A_{645}$ and $A_{663}$ are the absorbance at 645 and $663 \mathrm{~nm}, V$ is the volume in $\mathrm{mL}, a$ is the length of the light path in the cell $(1 \mathrm{~cm})$, and $W$ is the fresh weight in grams [23].

\section{Determination of total soluble protein content in leaf and root}

The total soluble protein content of $0.1 \mathrm{~g}$ of frozen leaf and roots was respectively determined by grinding each sample in $1.5 \mathrm{ml}$ of extraction buffer containing $50 \mathrm{mM}$ potassium phosphate buffer $\mathrm{pH} 7.5$ and 5 $\mathrm{mM}$ dithiothereitol (DTT) at $4^{\circ} \mathrm{C}$. The extract was centrifuged at $5,000 \times g$ for 15 minutes at $4^{\circ} \mathrm{C}$ and the supernatant was collected. The supernatant was kept at $4^{\circ} \mathrm{C}$ prior to protein and enzymes assays [24].

Protein solution $(10 \mu \mathrm{l})$ was pipetted into a test tube. Then, $90 \mu \mathrm{l}$ of extraction buffer (50 mM potassium phosphate buffer pH 7.5 containing $5 \mathrm{mM}$ DTT) was added into the protein solution. Afterwards, the Bradford working buffer was added and the mixture was vortexed. The absorbance was measured at $595 \mathrm{~nm}$ after 2 minutes of incubation time using glass cuvette. The absorbance reading of the samples was compared with a standard protein, the bovine serum albumin (BSA) [25]. The reading was taken in triplicate and the results were compared with a protein standard curve. The protein standard curve was plotted using BSA at range concentrations of $0.2-1.0 \mathrm{mg} / \mathrm{mL}$ as a standard protein. The total soluble protein was expressed as milligram per milligram fresh weight $(\mathrm{mg} / \mathrm{mg} \mathrm{FW})$.

\section{Determination of catalase (CAT) activity}

The CAT activity was assayed according to a method described by Azzeme et al. [16]. The $3 \mathrm{~mL}$ of reaction mixture consisting of $50 \mathrm{mM}$ potassium phosphate buffer $(\mathrm{pH} 7.0), 20 \mathrm{mM}$ of $30 \%$ hydrogen peroxide, and $50 \mu \mathrm{l}$ of crude extract was prepared. The CAT activity was determined by measuring absorbance at $240 \mathrm{~nm}$ after 3 minutes of incubation using LaboMed UV-VIS Spectrophotometer wherein the potassium phosphate buffer was used as a blank. The reading was carried out in triplicate. The enzyme activity was calculated as per its extinction coefficient of $36 \mathrm{mM} / \mathrm{cm}$. The enzyme activity was expressed as $\mu$ mole per min per milligram protein ( $\mu \mathrm{mole} / \mathrm{min} / \mathrm{mg}$ protein).

\section{Guaiacol peroxidase (POD) assay}

The $3 \mathrm{~mL}$ of reaction mixture consisting of $0.1 \mathrm{mM}$ potassium phosphate buffer (pH 6.0), $7.5 \mathrm{mM}$ of $30 \%$ of hydrogen peroxide, $15 \mathrm{mM}$ of guaicol, and $50 \mu \mathrm{l}$ of crude extract was prepared. The POD activity was determined by measuring absorbance using LaboMed UV-VIS Spectrophotometer at $470 \mathrm{~nm}$ after 3 
minutes of incubation time. The potassium phosphate buffer was used as a blank solution. The experiment was carried out in triplicate. The enzyme activity was calculated as per its extinction coefficient of $25 \mathrm{mM} / \mathrm{cm}$. The enzyme activity was expressed as $\mu$ mole per min per milligram protein ( $\mu \mathrm{mole} / \mathrm{min} / \mathrm{mg}$ protein) [16].

\section{Ascorbate peroxidase (APX) assay}

The $3 \mathrm{~mL}$ of reaction mixture consisting of $0.1 \mathrm{mM}$ potassium phosphate buffer $(\mathrm{pH} 7.0), 1 \mathrm{mM}$ of $30 \%$ of hydrogen peroxide, $1 \mathrm{mM}$ of ethylenediaminetetraacetic acid (EDTA), and $50 \mu \mathrm{l}$ of crude extract was prepared. The APX activity was determined by measuring absorbance at $290 \mathrm{~nm}$ after 3 minutes of incubation time. Potassium phosphate buffer was then used as a blank solution. The experiment was carried out in triplicate. The enzyme activity was calculated as per its extinction coefficient of $2.8 \mathrm{mM} / \mathrm{cm}$. The enzyme activity was expressed as $\mu$ mole per min per milligram protein (umole/min/mg protein) [16].

\section{Determination of total proline content}

Proline content was determined according to a method described by Bates et al. [26]. The total proline was extracted by homogenizing the leaf $(0.3 \mathrm{~g})$ in the $6 \mathrm{~mL}$ of aqueous sulfosalicyclic acid. The mixture was centrifuged at $13,000 \times g$ for 30 minutes. Then, $2 \mathrm{~mL}$ of supernatant was taken and mixed with 2 $\mathrm{mL}$ of ninhydrin solution and $2 \mathrm{~mL}$ of glacial acid in the test tube. The mixture was incubated for 1 hour at $100^{\circ} \mathrm{C}$. After 1 hour, the mixture was immediately incubated on ice for 5 minutes to terminate the reaction. Toluene $(4 \mathrm{~mL})$ was added into the mixture and the reaction mixture was mixed vigorously using micropipette. The absorbance reading was taken at $520 \mathrm{~nm}$ using toluene as a blank. The reading was taken in triplicate. The total proline content was expressed as $\mu$ mole proline per gram fresh weight $(\mu \mathrm{moles} / \mathrm{g} \mathrm{FW})$. The proline concentration was determined from a standard curve and calculated on a fresh weight basis using following equation:

$$
\mu \text { moles proline/ gram of fresh weight material }=[(\mu \mathrm{g} \text { proline } / \mathrm{mL} \times \mathrm{mL} \text { toluene }) / 115.5
$$
$\mu \mathrm{g} / \mu \mathrm{mole}] /[(\mathrm{g}$ sample $) / 5]$

\section{Statistical analysis}

The data of each parameter were subjected to one-way analysis of variance (ANOVA). The significant of the difference between the means was determined by Tukey's multiple range test ( $p \leq 0.05)$ using SPSS (Statistical Packages for the Social Sciences) software. The values were expressed as means of triplicate determinations \pm standard error (SE).

\section{Results and discussion}

In this study, PEG has capability to induce drought stress or osmotic stress for in vitro Lang banana. PEG is a high molecular weight compound that has been exploited as an osmotic agent to block the absorption of water through plant roots. The blockage leads the plants to suffer dehydration, and therefore mimicking drought stress condition [4,27]. In this study, PEG with a molecular weight of 8000 dalton was utilized because it has been proven to have an ability to induce osmotic stress in banana $[28,29,30,31]$. From our observation, the application of PEG 8000 had affected the growth of leaf and roots of Lang banana plantlets. The number of leaves increased in all PEG treatments (Table 1). The increment is probably due to physiological adjustment of plantlets in order to maintain photosynthesis under unfavorable condition. These findings were contradictory with previous findings that showed reduction of leaf number in PEG-stressed banana plantlets as reported by Ismail et al. [32] for Mas and Berangan cultivars and Said et al. [9] for Grand Nain cultivar. Therefore, the present findings suggest the involvement of antioxidant activities in treated Lang banana plantlets that might facilitate the maintenance of cell division in leaf. This response was also observed in tolerant maize hybrid [33]. Application of PEG in the culture media also negatively affected the average root length of the Lang banana plantlets as compared to the control media (Table 1), which the decrement of average root length 
was observed from $9.84 \pm 0.55 \mathrm{~cm}$ to $3.43 \pm 0.66 \mathrm{~cm}$. The decrement of root length in this study was in line with a study conducted by Said et al. [9] for PEG-treated Grand Nain cultivar. The decrement of root length is probably due to the disruption of root meristem cells, therefore disrupting cell division and elongation processes. Accumulation of abscisic acid in Lang banana roots might also be a reason of root inhibition. As reported by Brunner et al. [34], the root growth inhibition in plant responding to drought stress is due to abscisic acid accumulation in the stressed cells.

Table 1. The number of leaves, number of roots, and length of roots $(\mathrm{cm})$ of Lang banana plantlets treated with different concentrations of PEG. Means with different letters are significantly different at $p \leq 0.05$ by Tukey's Test.

\begin{tabular}{|c|c|c|c|}
\hline PEG Treatment (\%) & Number of leaves & Number of roots & Length of roots $(\mathrm{cm})$ \\
\hline 0 & $5 \pm 0.61^{\mathrm{b}}$ & $7 \pm 0.11^{\mathrm{a}}$ & $9.84 \pm 0.55^{\circ}$ \\
\hline 1 & $7 \pm 0.75^{c}$ & $6 \pm 0.28^{b}$ & $6.68 \pm 0.33^{b}$ \\
\hline 2 & $7 \pm 0.69^{c}$ & $7 \pm 0.24^{b}$ & $6.24 \pm 0.58^{c}$ \\
\hline $\begin{array}{l}3 \\
4\end{array}$ & $\begin{array}{l}6 \pm 0.17^{a} \\
7 \pm 0.89^{c}\end{array}$ & $\begin{array}{l}4 \pm 0.51^{d} \\
7 \pm 0.55^{d}\end{array}$ & $\begin{array}{l}3.43 \pm 0.66^{d} \\
5.98 \pm 0.25^{a}\end{array}$ \\
\hline 5 & $6 \pm 0.13^{a}$ & $7 \pm 0.33^{c}$ & $7.46 \pm 0.57^{c}$ \\
\hline
\end{tabular}

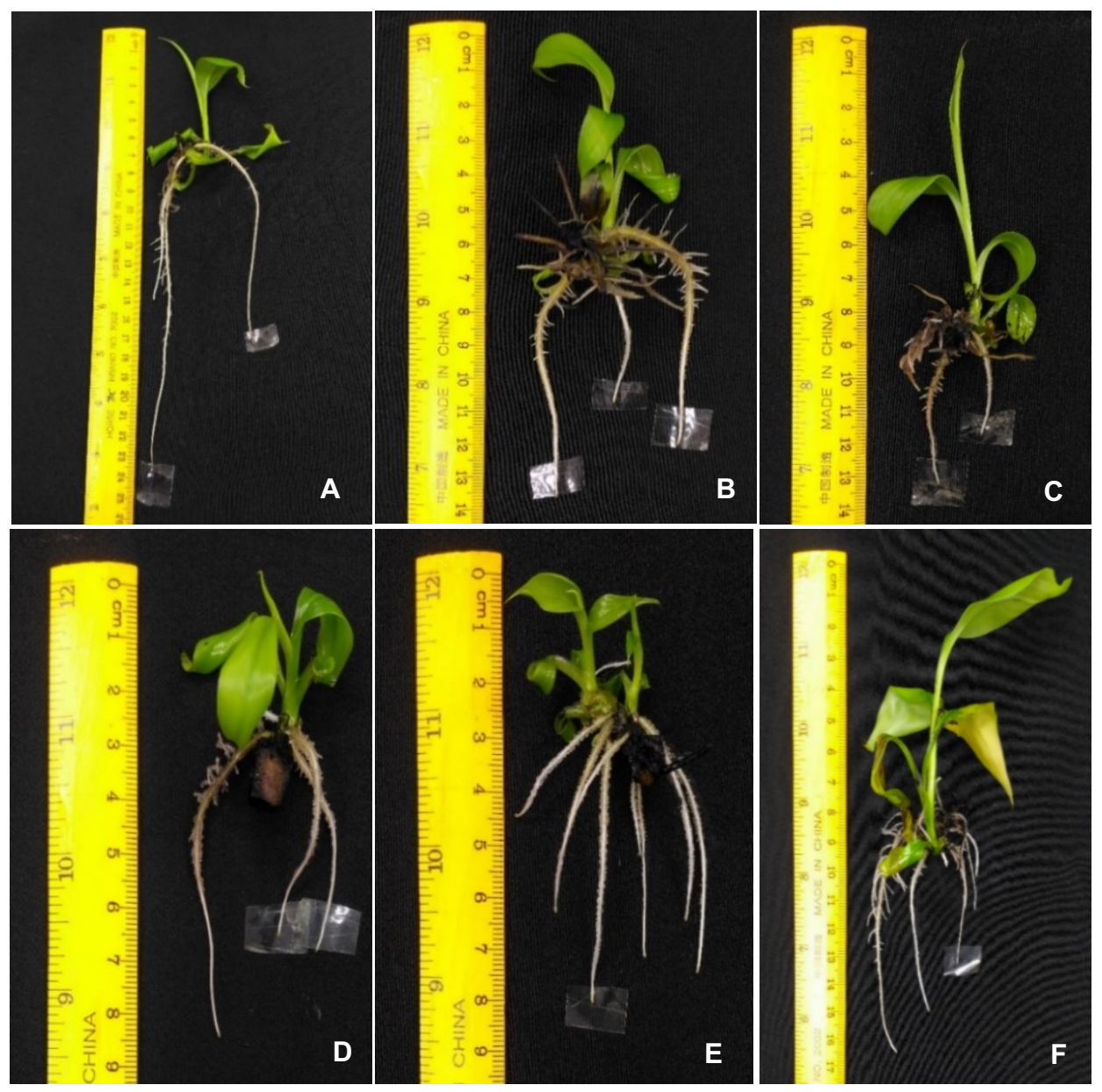

Figure 1. Morphological appearance of Lang banana plantlets after 3 weeks of exposure to different concentrations of PEG 8000. (A) Control plantlet; (B) $1 \%$ of PEG treated plantlet; (C) $2 \%$ of PEG treated plantlet; (D) $3 \%$ of PEG treated plantlet; (E) $4 \%$ of PEG treated plantlet; (F) $5 \%$ of PEG treated plantlet. 
Lipid peroxidation that arises due to osmotic stress can induce chlorophyll degradation [35,36]. In this study, the leaf color of stressed plantlets changed from green to yellow when they were exposed to PEG, showing the disruption of photosynthesis. The clear observation can be seen when PEG exposure was increased to $5 \%$ as shown in Figure 1F. The alteration of leaf color might be due to the chlorophyll degradation, which was proven by chlorophyll content analysis (Table 2). The total chlorophyll content, $\mathrm{Chl} a, \mathrm{Chl} b$, and ratio of $\mathrm{Chl}_{a}: \mathrm{Chl}_{\mathrm{b}}$ were decreased when responding to all PEG concentrations. The activation of chlorophyllase enzyme might be a significant reason for depletion of chlorophyll content as reported by Mihailović et al. [37]. Chlorophyllase is one of important enzymes involved in chlorophyll metabolism that catalyzes the hydrolysis of chlorophyll into chlorophyllide and phytol [38]. In a study conducted by Haider et al. [39], the pheophorbide a oxygenase (PAO) was up-regulated in Prunus persica L. under drought. PAO involves in degradation of chlorophyllide a into non-fluorescent chlorophyll catabolites. Similar observations were also reported by previous studies in banana $[40,41]$ and other plants $[12,42]$.

Table 2. Total Chlorophyll a (Chl a) content, total chlorophyll $b(\mathrm{Chl} b)$ content, total chlorophyll (TC) content and Chl $a$ :Chl $b$ ratio in the leaf tissue of Lang banana plantlets treated with different concentrations of PEG. Means with different letters are significantly different at $p \leq 0.05$ by Tukey's Test.

\begin{tabular}{ccccc}
\hline PEG Treatment (\%) & Chl $\boldsymbol{a}(\mathbf{m g} / \mathbf{g}$ FW) & Chl $\boldsymbol{b}(\mathbf{m g} / \mathbf{g ~ F W})$ & TC $(\mathbf{m g} / \mathbf{g ~ F W})$ & Chl $\mathbf{a}: \mathbf{C h l} \boldsymbol{b}$ \\
\hline 0 & $2.39 \pm 0.02^{\mathrm{d}}$ & $0.95 \pm 0.02^{\mathrm{b}}$ & $3.33 \pm 0.24^{\mathrm{b}}$ & $2.4^{\mathrm{b}}$ \\
1 & $1.26 \pm 0.12^{\mathrm{b}}$ & $0.54 \pm 0.10^{\mathrm{b}}$ & $1.81 \pm 0.13^{\mathrm{ab}}$ & $2.6^{\mathrm{bc}}$ \\
2 & $1.25 \pm 0.03^{\mathrm{bc}}$ & $0.57 \pm 0.04^{\mathrm{b}}$ & $1.82 \pm 0.04^{\mathrm{ab}}$ & $2.0^{\mathrm{ab}}$ \\
3 & $0.57 \pm 0.04^{\mathrm{a}}$ & $0.29 \pm 0.08^{\mathrm{a}}$ & $0.87 \pm 0.03^{\mathrm{a}}$ & $2.0^{\mathrm{ab}}$ \\
4 & $1.64 \pm 0.03^{\mathrm{c}}$ & $0.61 \pm 0.11^{\mathrm{b}}$ & $2.25 \pm 0.14^{\mathrm{ab}}$ & $2.7^{\mathrm{bc}}$ \\
5 & $0.52 \pm 0.02^{\mathrm{a}}$ & $0.51 \pm 0.13^{\mathrm{b}}$ & $1.03 \pm 0.22^{\mathrm{a}}$ & $1.0^{\mathrm{a}}$ \\
\hline
\end{tabular}

Proline is an amino acid, which is known to involve in cell osmotic adjustment and cell component protection during drought stress $[43,44]$. Figure 2 shows the highest accumulation of total proline content in Lang banana plantlets treated with $2 \%$ of PEG $(12.66 \pm 0.38 \mu \mathrm{mole} / \mathrm{g} \mathrm{FW})$ followed by $1 \%$ of PEG $(10.68 \pm 0.03 \mu \mathrm{mole} / \mathrm{g} \mathrm{FW})$ and $3 \%$ of PEG $(9.00 \pm 4.38 \mu \mathrm{mole} / \mathrm{g} \mathrm{FW})$ compared to that of control $(8.28 \pm 0.44 \mu \mathrm{mole} / \mathrm{g} \mathrm{FW})$. The total proline content was significantly decreased in plantlets treated with $5 \%$ of PEG $(6.44 \pm 0.78 \mu \mathrm{mole} / \mathrm{g} \mathrm{FW})$ and $4 \%$ of PEG $(4.81 \pm 0.04 \mu \mathrm{mole} / \mathrm{g} \mathrm{FW})$ compared to control. The findings therefore show an ability of Lang banana plantlets to accumulate high proline to maintain cell turgor under osmotic stress. This may allow cell enlargement and adaptation of plant growth under water stress. The proline also allows stomata to remain at least partially opened for $\mathrm{CO}_{2}$ assimilation to continue [20,45]. The proline produced may also react as nonenzymatic antioxidant, therefore, it can protect cell from injuries due to high production of ROS. However, when there is high accumulation of enzymatic antioxidant in cell, the condition may cause the decrement of total proline content [46]. 


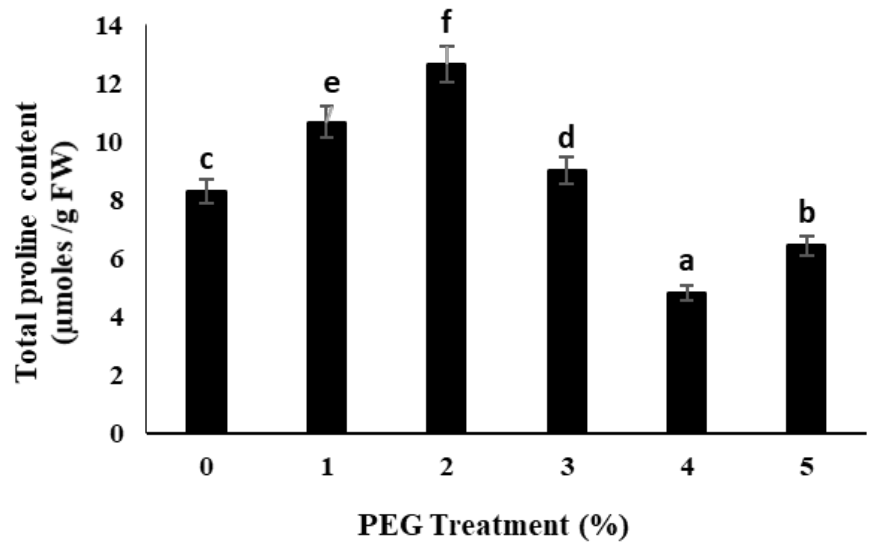

Figure 2. Effect of different concentrations of PEG on the total proline content in leaf of Lang banana plantlets. Data represent as means \pm SE. Different letters represent as significant difference at $\mathrm{p} \leq 0.05$ Tukey's range test.

The total soluble protein content of PEG treated leaf was significantly decreased compared to that of control $(36.28 \pm 3.24 \mathrm{mg} / \mathrm{g} \mathrm{FW}$ ) (Figure 3A). The total soluble protein content in leaf treated with $1 \%, 2 \%$, $3 \%, 4 \%$, and $5 \%$ were $7.49 \pm 1.53,34.50 \pm 3.46,10.14 \pm 1.36 \mathrm{mg} / \mathrm{g} \mathrm{FW}, 12.74 \pm 2.49$, and $10.85 \pm 0.99 \mathrm{mg} / \mathrm{g}$ FW, respectively suggesting the accumulation of different drought related proteins. The reduction of total soluble protein content in leaf might also be due to immediate decrease of photosynthetic proteins especially Rubisco. It is because $80 \%$ of total soluble proteins in many plants are derived from Rubisco, which is a key enzyme in Calvin cycle [41]. The significant decrease of total soluble protein content in banana leaf was also observed in Karpuravalli, Karpuravalli x PisangJajee, Saba, Sanna Chenkathali, Poovan, Ney poovan, Anaikomban, Matti x Cultivar Rose, Matti, Pisang Jajee x Matti, Matti $x$ Anaikomban, and Anaikomban $x$ Pisang Jajee cultivars [47]. In Lang banana roots, the total soluble protein content was only decreased in $1 \%$ and $3 \%$ of PEG treated plantlets. The protein content however increased in $2 \%(28.05 \pm 6.67 \mathrm{mg} / \mathrm{mg} \mathrm{FW}), 4 \%(25.10 \pm 0.44 \mathrm{mg} / \mathrm{mg} \mathrm{FW})$, and $5 \%(30.65 \pm 1.07 \mathrm{mg} / \mathrm{mg}$ FW) of PEG treated plantlets compared to that of control $(23.90 \pm 3.42 \mathrm{mg} / \mathrm{g} \mathrm{FW}$ ) (Figure 3B). The adjustment of protein content in roots is probably due to the direct contact of roots to PEG containing media that sense the drought stress. Similar findings were also reported in rice by Agrawal et al. [48] and banana by Amnan et al. [49]. Further, the root is the first organ that perceives the drought signal. Thus, the higher protein content in roots under all PEG treatments compared to the leaf is due to accumulation of stress-responsive proteins to protect the root cell from drought stress [41].
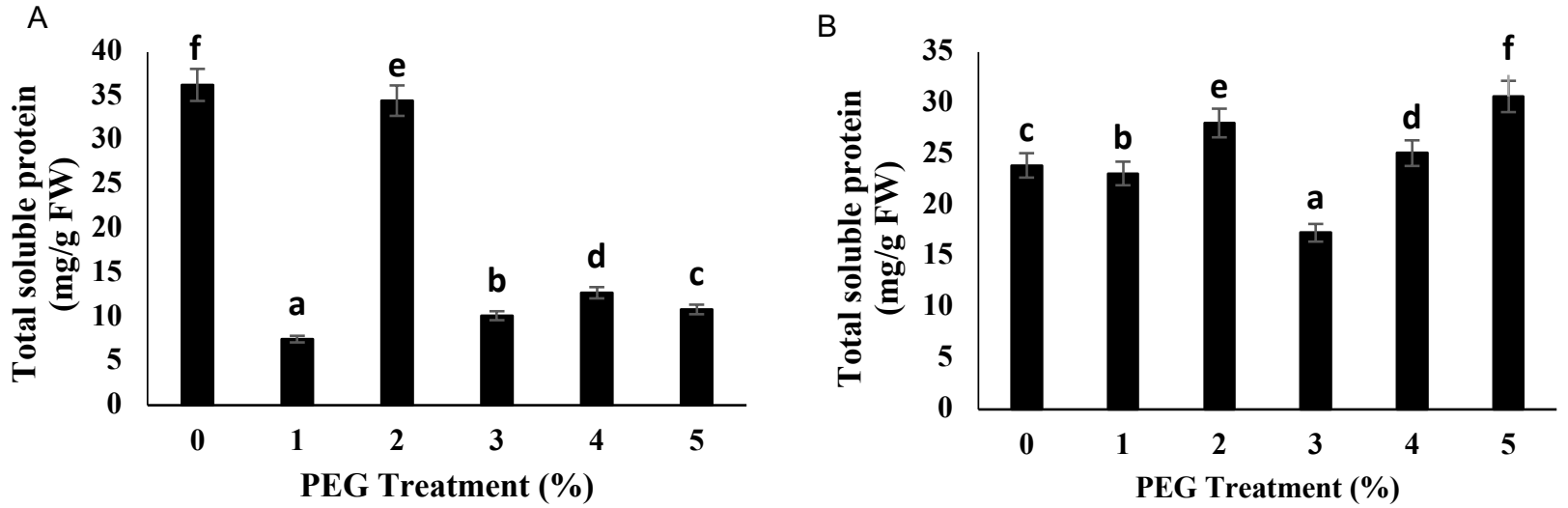

Figure 3. Effect of different concentrations of PEG treatment on the total soluble protein content in (A) leaf and (B) root of Lang banana plantlets. Data represent as means \pm SE. Different letters represent as significantly different at $p \leq 0.05$ Tukey's range test. 
Drought stress exposure activates enzymatic antioxidants [50]. In this study, the activities of CAT, POD, and APX were analyzed. Overall, the present findings showed the different modulations of CAT activity in leaf and roots of Lang banana during combating against drought stress. The CAT activity in leaf was significantly increased compared to control $(0.21 \pm 0.02 \mu \mathrm{mol} / \mathrm{min} / \mathrm{mg}$ protein). The highest CAT activity was observed in the leaf treated with $1 \%$ of PEG $(10.69 \pm 0.56 \mu \mathrm{mol} / \mathrm{min} / \mathrm{mg}$ protein) followed by $5 \%$ of PEG $(7.52 \pm 0.55 \mu \mathrm{mol} / \mathrm{min} / \mathrm{mg}$ protein), $3 \%$ of PEG $(3.78 \pm 0.31 \mu \mathrm{mol} / \mathrm{min} / \mathrm{mg}$ protein), $4 \%$ of PEG $(3.44 \pm 0.95 \mu \mathrm{mol} / \mathrm{min} / \mathrm{mg}$ protein), and $2 \%$ of PEG $(1.91 \pm 0.48 \mu \mathrm{mol} / \mathrm{min} / \mathrm{mg}$ protein) (Figure $4 \mathrm{~A})$. The reduction of CAT activity was observed in roots of plantlets treated with $2 \%$ of PEG $(0.36 \pm 0.01$ $\mu \mathrm{mol} / \mathrm{min} / \mathrm{mg}$ protein) followed by $4 \%$ of PEG $(0.35 \pm 0.14 \mu \mathrm{mol} / \mathrm{min} / \mathrm{mg}$ protein) and $5 \%$ of PEG $(0.27 \pm 0.12 \mu \mathrm{mol} / \mathrm{min} / \mathrm{mg}$ protein) compared to that of control $(0.41 \pm 0.01 \mu \mathrm{mol} / \mathrm{min} / \mathrm{mg}$ protein) (Figure 4). However, the CAT activity in roots was higher than control plantlets treated with $3 \%$ of $P E G$ and $1 \%$ of PEG. The decrease in CAT activity in stressed plantlets is due to an increase accumulation of lipid peroxidation, which produces ROS that can cause loss of protective function of antioxidant enzymes that protect the plant [51]. Previous study on pigeon pea reported that CAT activity decreased after PEG exposure $(1.33 \pm 0.42 \mu \mathrm{mol} / \mathrm{min} / \mathrm{mg}$ protein) compared to control $(2.20 \pm 0.86 \mu \mathrm{mol} / \mathrm{min} / \mathrm{mg}$ protein) [52]. Meanwhile, the high CAT activity is probably due to the involvement of CAT in protecting leaf tissue against drought stress.
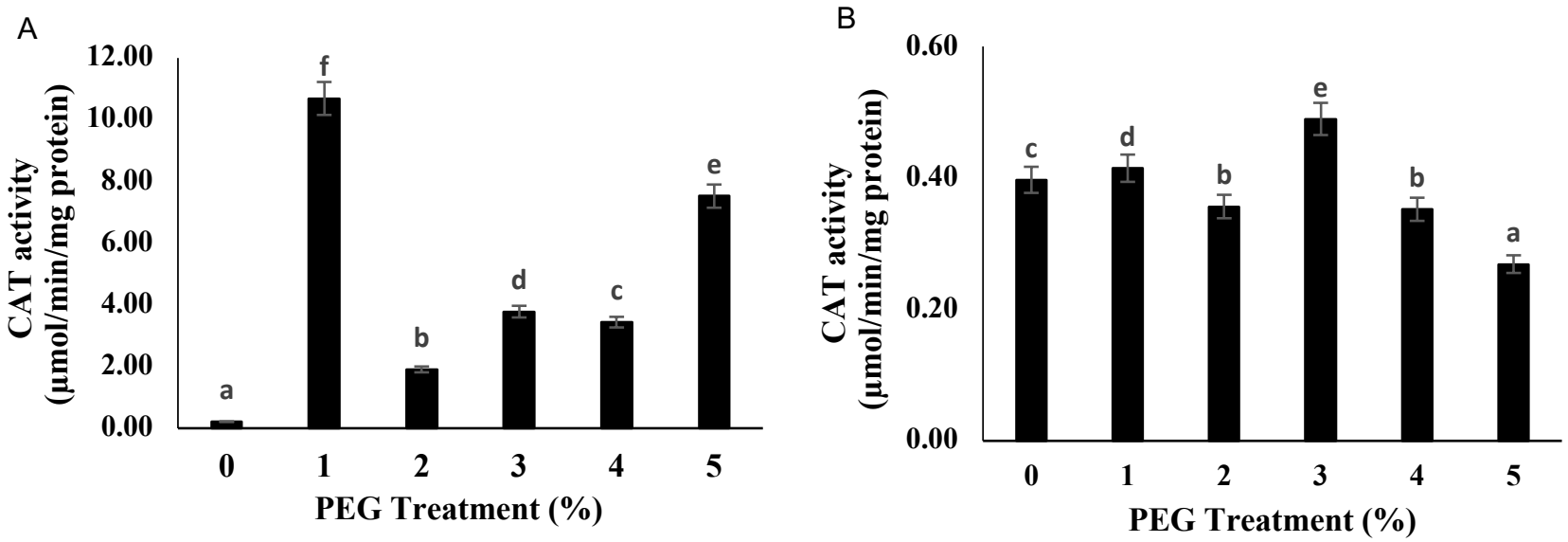

Figure 4. Effect of different PEG concentrations on catalase (CAT) activity in (A) leaf and (B) roots of Lang banana plantlets. Data represent as means $\pm S E$. Different letters represent as significantly different at $p \leq 0.05$ Tukey's range test.

The highest POD activity in leaf was observed in plantlets treated with $4 \%$ of PEG $(0.079 \pm 0.03$ $\mu \mathrm{mol} / \mathrm{min} / \mathrm{mg}$ protein), followed by $1 \%$ and $3 \%$ of PEG compared to control $(0.025 \pm 0.04 \mu \mathrm{mol} / \mathrm{min} / \mathrm{mg}$ protein). The POD activities in $5 \%$ of PEG $(0.043 \pm 0.08 \mu \mathrm{mol} / \mathrm{min} / \mathrm{mg}$ protein $)$ and $2 \%$ of PEG $(0.029 \pm 0.02$ $\mu \mathrm{mol} / \mathrm{min} / \mathrm{mg}$ protein) treated plantlets were significantly reduced compared to control as shown in Figure $5 \mathrm{~A}$. The different trends of POD activity were also observed in roots. The POD activity was significantly increased in roots treated with $2 \%$ of PEG $(0.029 \pm 0.02 \mu \mathrm{mol} / \mathrm{min} / \mathrm{mg}$ protein) and $3 \%$ of PEG $(0.012 \pm 0.01 \mu \mathrm{mol} / \mathrm{min} / \mathrm{mg}$ protein) compared to that of control $(0.008 \pm 0.02 \mu \mathrm{mol} / \mathrm{min} / \mathrm{mg}$ protein) (Figure 5). Guo et al. [53] also determined similar finding for POD extracted from root and leaf of Lycium ruthenicum Murr. However, POD activity was reported to be increased in all treatments in maize [54]. The variation trends in enzymatic activities in plants are most probably due to the different plant species, plants age, treatment durations, and experimental conditions [55]. Apart from that, the different stress levels received by the banana plantlets might also interfere the three-dimensional structure of the enzyme as reported by Azzeme et al. [16]. Thus, POD enzyme in the Lang banana root might also be affected by the drought stress. In present study, the scavenging activity of hydrogen peroxide in root was led by APX. 
A

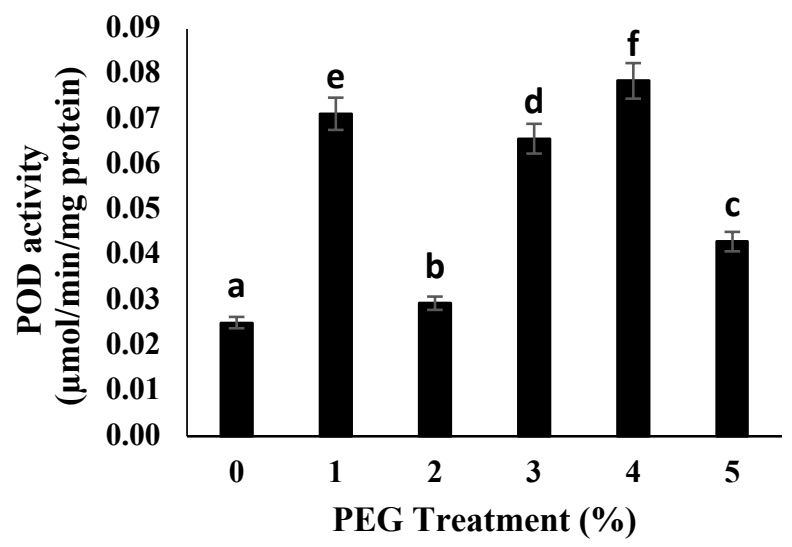

B

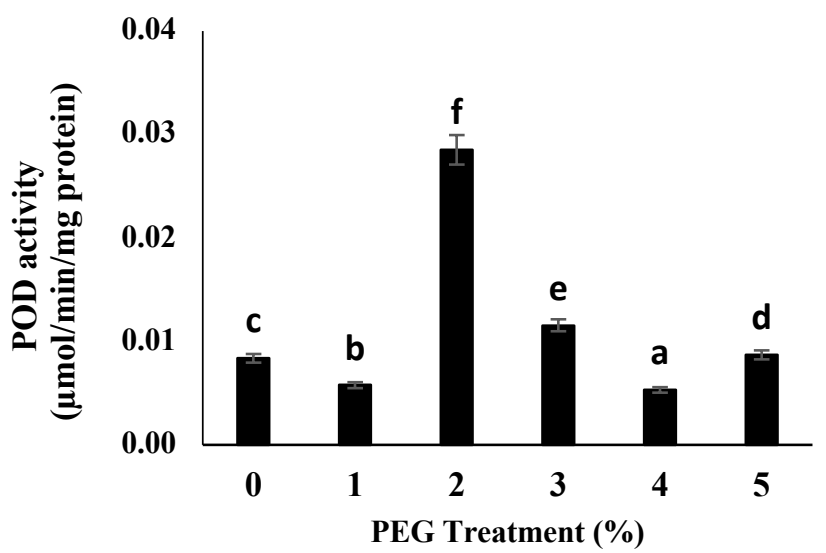

Figure 5. Effect of different concentrations of PEG treatment on guaiacol peroxidase (POD) activity in (A) leaf and (B) root of Lang banana plantlets. Data represent as means \pm SE. Different letters represent as significantly different at $p \leq 0.05$ Tukey's range test.

A

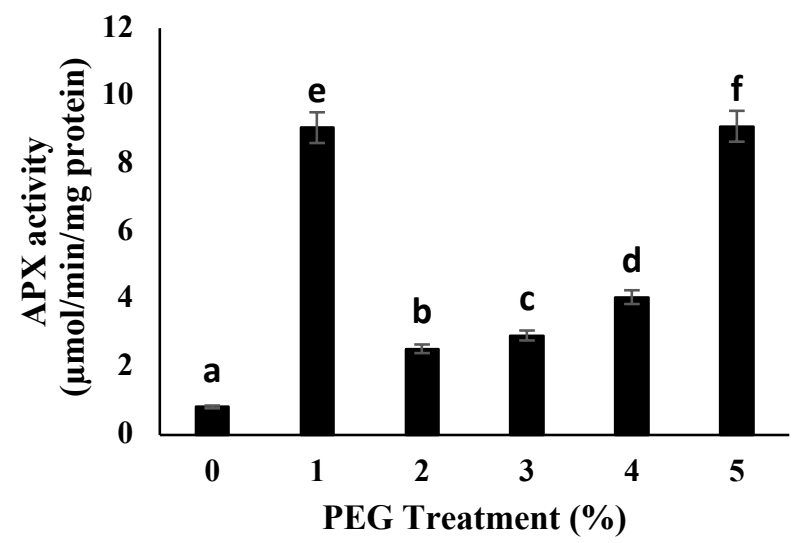

B

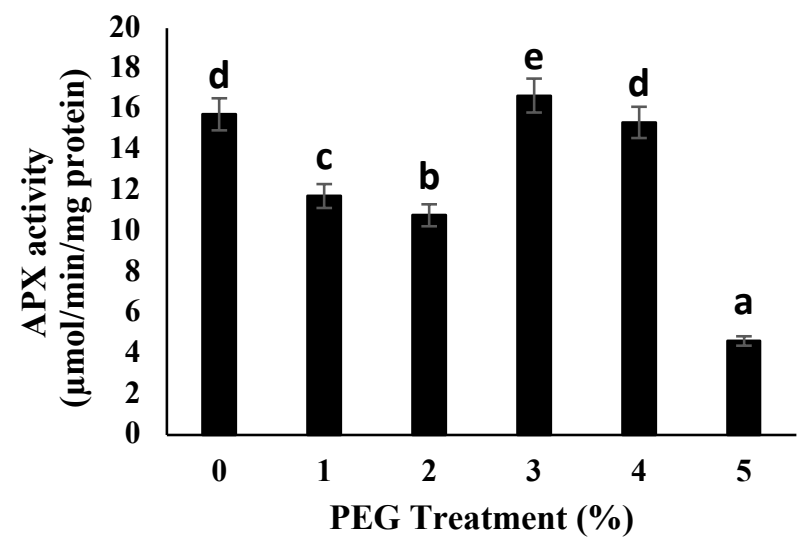

Figure 6. Effect of different PEG concentrations on ascorbate peroxidase (APX) activity in (A) leaf and (B) roots of Lang banana plantlets. Data represent as means \pm SE. Different letters represent as significantly different at $p \leq 0.05$ Tukey's range test.

The APX activity in leaf was significantly increased compared to control plantlets $(0.83 \pm 0.30$ $\mu \mathrm{mol} / \mathrm{min} / \mathrm{mg}$ protein). The highest APX activity in leaf was observed in plantlets treated with $5 \%$ of PEG $(9.11 \pm 8.47 \mu \mathrm{mol} / \mathrm{min} / \mathrm{mg}$ protein) followed by $1 \%$ of PEG $(9.07 \pm 2.71 \mu \mathrm{mol} / \mathrm{min} / \mathrm{mg}$ protein $), 4 \%$ of PEG $(4.07 \pm 4.73 \mu \mathrm{mol} / \mathrm{min} / \mathrm{mg}$ protein), $3 \%$ of PEG $(2.93 \pm 7.03 \mu \mathrm{mol} / \mathrm{min} / \mathrm{mg}$ protein), and $2 \%$ of PEG $(2.54 \pm 0.51 \mu \mathrm{mol} / \mathrm{min} / \mathrm{mg}$ protein) (Figure $6 \mathrm{~A})$. APX has a high affinity in eliminating hydrogen peroxide even in a small amount. Moreover, APX has an ability to keep hydrogen peroxide concentration low when plants are under stress condition [56]. Previous study reported that APX activity of moderate drought stress $(2.7 \mu \mathrm{mol} / \mathrm{min} / \mathrm{mg}$ protein) and severe drought stress $(3.2 \mu \mathrm{mol} / \mathrm{min} / \mathrm{mg}$ protein $)$ decreased compared to control $(3.8 \mu \mathrm{mol} / \mathrm{min} / \mathrm{mg}$ protein) in citrus plant. This is due to the high proline content that becomes a main compound to prevent ROS, and APX may not be involved in preventing ROS in the cell [57]. The significant increase of APX activity under 5\% of PEG treatment in leaf might be due to incorporation of APX with other antioxidant enzymes such as CAT to induce more tolerance to drought stress. The APX and other enzymes are also reported to involve in the ascorbate-glutathione cycle. The overexpression of $A P X$ with other antioxidant enzymes leads to the increase tolerance under environmental stress [58]. Meanwhile, the reduction of APX under severe stress condition in root could 
be due to instability of enzyme structure as reported happened to POD enzyme. Therefore, it could be observed that in general the stability of antioxidant enzymes is dependent on the strength of the stress received by the plants.

Overall, the APX activity was significantly decreased in roots of Lang banana plantlets treated with $1 \%$ of PEG $(11.75 \pm 0.41 \mu \mathrm{mol} / \mathrm{min} / \mathrm{mg}$ protein), $2 \%$ of PEG $(10.80 \pm 0.67 \mu \mathrm{mol} / \mathrm{min} / \mathrm{mg}$ protein), $4 \%$ of PEG (15.37 $\pm 0.40 \mu \mathrm{mol} / \mathrm{min} / \mathrm{mg}$ protein), and $5 \%$ of PEG $(4.52 \pm 2.85 \mu \mathrm{mol} / \mathrm{min} / \mathrm{mg}$ protein) compared to control $(15.77 \pm 0.73 \mu \mathrm{mol} / \mathrm{min} / \mathrm{mg}$ protein) as shown in Figure 6B. However, the $3 \%$ of PEG treated plantlets showed slightly higher in the APX activity compared to control. Thus, the findings suggest the high accumulation of hydrogen peroxide in Lang banana roots could be a factor of decrement of APX activity. It is because APX is reported can immediately inactivate under excess production of hydrogen peroxide, which can cause cellular damage in the drought-stressed cell [59].

\section{Conclusions}

The PEG treatment had significantly affected the Lang banana growth. The root length and total chlorophyll content of treated plantlets decreased in response to PEG treatment. The total proline content however increased in leaf with the increment of PEG concentrations but the decrement of proline content in leaf was observed in plantlets treated with high concentration of PEG. Meanwhile, variation amount of total soluble protein content was quantified in leaf and roots of treated plantlets. For enzymatic antioxidants, the CAT, POD, and APX activities were found the highest in roots, yet in the leaf the findings showed variation in activities of CAT, POD, and APX. Therefore, based on these findings, we found that Lang banana plantlets have capability to develop defense mechanisms by modulating physiobiochemical responses when they responding to different concentrations of PEG.

\section{Conflicts of interest}

The authors declare that there is no conflict of interest regarding the publication of this paper.

\section{Acknowledgments}

This research was funded by Putra Graduate Initiative (IPS) grant (GP-IPS/2017/9527000) and Yayasan Pak Rashid Short Term Research Grant, Universiti Putra Malaysia, Malaysia.

\section{References}

[1] Huang YF, Ang JT, Tiong YJ, Mirzaei M, Amin MZM (2016). Drought forecasting using SPI and EDI under RCP8.5 climate change scenarios for Langat River Basin, Malaysia. Procedia Engineering 154:710-717.

[2] Zandalinas SI, Mittler, R, Balfagón D, Arbona V, Gómez-Cadenas A (2018). Plant adaptations to the combination of drought and high temperatures. Physiologia Plantarum 162(1):2-12.

[3] Ravi I, Uma S, Vaganan MM, Mustaffa MM (2013). Phenotyping bananas for drought resistance. Frontiers in Physiology 4:1-15.

[4] Chutia J, Borah SP (2012). Water stress effects on leaf growth and chlorophyll content but not the grain yield in traditional rice (Oryza sativa Linn.) Genotypes of Assam, India II. protein and proline status in seedlings under peg induced water stress. American Journal of Plant Sciences 3(7):971-980.

[5] Nansamba M, Sibiya J, Tumuhimbise R, Karamura D, Kubiriba J, Karamura E (2020). Breeding banana (Musa spp.) for drought tolerance: A review. Plant Breeding 139:685-696.

[6] National Research Centre for Banana (ICAR) (2008). 2008 annual report. Trichy, India: Anon.

[7] Abdullah FC, Vun YL, Wali HSM, Sundaraj Y, Khamis S (2011). Peeling the scientific facts of banana. Shah Alam, Selangor: International Islamic Academy for Life Science and Biotechnology.

[8] Ramlan NN, Azzeme AM, Padzil KN, Mahmood M (2017). Influence of different extraction solvents on phytochemical content and antioxidant capacity extracted from pulp and flower of dessert and cooking bananas. Malaysian Journal of Biochemistry \& Molecular Biology 2\&3:10-16.

[9] Said EM, Mahmoud RA, Al-Akshar R, Shafwat G (2015). Drought stress tolerance and enhancement of banana plantlets in vitro. Austin Journal of Biotechnology and Bioengineering 2(2):1040-1047.

[10] Hamayun M, Khan SA, Shinwari ZK, Khan AL, Ahmad N, Lee IJ (2010). Effect of polyethylene glycol induced 
drought stress on physio-hormonal attributes of soybean. Pakistan Journal of Botany 42(2):977-986.

[11] Saglam A, Terzi R, Demiralay M (2014). Effect of polyethylene glycol induced drought stress on photosynthesis in two chickpea genotypes with different drought tolerance. Acta Biologica Hungarica 65(2):178-188.

[12] Azzeme AM, Abdullah SNA, Aziz MA, Wahab PEM (2017). Oil palm drought inducible DREB1 induced expression of DRE/CRT- and non-DRE/CRT-containing genes in lowland transgenic tomato under cold and PEG treatments. Plant Physiology and Biochemistry 112:129-151

[13] Meher, Shivakrishn P, Reddy KA, Rao DM (2018). Effect of PEG-6000 imposed drought stress on RNA content, relative water content (RWC), and chlorophyll content in peanut leaves and roots. Saudi Journal of Biological Sciences 25(2):285-289.

[14] Cai K, Chen X, Han Z, Wu X, Zhang S, Li Q, Nazir MM, Zhang G, Zeng F (2020). Screening of worldwide barley collection for drought tolerance: The assessment of various physiological measures as the selection criteria. Frontiers in Plant Science 11:1159.

[15] Lodish H, Berk A, Zipursky SL, Matsudaira P, Baltimore D, Darnell J (2000). Molecular cell biology, $4^{\text {th }}$ edition. United State, New York: W. H. Freeman.

[16] Azzeme AM, Abdullah SNA, Aziz MA, Wahab PEM (2016). Oil palm leaves and roots differ in physiological response, antioxidant enzyme activities and expression of stress-responsive genes upon exposure to drought stress. Acta Physiologiae Plantarum 38(2):52-64.

[17] Hasanuzzaman M, Bhuyan MHM, Zulfiqar F, Raza A, Mohsin SM, Mahmud JA, Fujita M, Fotopoulos V (2020). Reactive oxygen species and antioxidant defense in plants under abiotic stress: revisiting the crucial role of a universal defense regulator. Antioxidants 9(8):681-733.

[18] Sharma P, Jha AB, Dubey RS, Pessarakli M (2012). Reactive oxygen species, oxidative damage, and antioxidative defense mechanism in plants under stressful conditions. Journal of Botany 2012:1-26.

[19] Król A, Amarowicz R, Weidner S (2014). Changes in the composition of phenolic compounds and antioxidant properties of grapevine roots and leaves (Vitis vinifera L.) under continuous of long-term drought stress. Acta Physiologiae Plantarum 36(6):1491-1499.

[20] Man D, Bao YX, Han LB, Zhang X (2011). Drought tolerance associated with proline and hormone metabolism in two tall fescue cultivars. Horticultural Science 46(7):1027-1032.

[21] Murashige T, Skoog F (1962). A revised medium for rapid growth and bioassays with tobacco cultures. Physiologia Plantarum 15(5):473-497.

[22] Gamborg OL, Miller RA, Ojima K (1968) Nutrient requirements of suspension cultures of soybean root cells. Experimental Cell Research 50:151-158.

[23] Harborne JB (1973). Phytochemical methods. Chapman and Hall, London.

[24] Arora A, Choudhary D, Agarwal G, Singh VP (2008). Compositional variation in $\beta$-carotene content, carbohydrate and antioxidant enzymes in selected banana cultivars. International Journal of Food Science and Technology 43(11):1913-1921.

[25] Bradford MM (1976). A rapid and sensitive method for the quantitation of microgram quantities of protein utilizing the principle of protein-dye binding. Analytical Biochemistry 72(1-2):248-254.

[26] Bates LS, Walden RP, Teare ID (1973). Rapid determination of free proline for water-stress studies. Plant and Soil 39(1):205-207. https://doi.org/10.1007/BF00018060

[27] Osmolovskaya N, Shumilina J, Kim A, Didio A, Grishina T, Bilova T, Keltsieva OA, Zhukov V, Tikhonovich I, Tarakhovskaya E, Frolov A (2018). Methodology of drought stress research: Experimental setup and physiological characterization. International Journal of Molecular Sciences 19(12):4089.

[28] Shekhawat UKS, Srinivas L, Ganapathi TR (2011). MusaDHN-1, a novel multiple stress-inducible SK3-Type dehydrin gene, contributes affirmatively to drought- and salt-stress tolerance in banana. Planta 234(5):915-932.

[29] Muthusamy M, Uma S, Backiyarani S, Saraswathi MS, Chandrasekar A (2016). Transcriptomic changes of drought-tolerant and sensitive banana cultivars exposed to drought stress. Frontiers in Plant Science 7:1609.

[30] Zorrilla-Fontanesi Y, Rouard M, Cenci A, Kissel E, Do H, Dubois E, Carpentier SC (2016). Differential root transcriptomics in a polyploid non-model crop: The importance of respiration during osmotic stress. Scientific Reports 6(1):25683.

[31] van Wesemael J, Hueber Y, Kissel E, Campos N, Swennen R, Carpentier S (2018). Homeolog expression analysis in an allotriploid non-model crop via integration of transcriptomics and proteomics. Scientific Reports 8(1):1353.

[32] Ismail MR, Yusoff MK, Mahmood M (2004). Growth, water relations, stomatal conductance and proline concentration in water stressed banana (Musa spp.) plants. Asian Journal of Plant Sciences 3:709-713.

[33] Avramova V, Abd Elgawad H, Vasileva I, Petrova AS, Holek A, Mariën J, Asard H, Beemster GT (2017). High antioxidant activity facilitates maintenance of cell division in leaves of drought tolerant maize hybrids. Frontiers in Plant Science. 8:84.

[34] Brunner I, Herzog C, Dawes MA, Arend M, Sperisen C (2015). How tree roots respond to drought. Frontiers in Plant Science 6:547.

[35] Ali Q, Ali S, Iqbal N, Javed MT, Rizwan M, Khaliq R, Shahid S, Perveen R, Alamri SA, Alyemeni MN, Wijaya L (2019). Alpha-tocopherol fertigation confers growth physio-biochemical and qualitative yield enhancement in field grown water deficit wheat (Triticum aestivum L.). Scientific Reports 9(1):12924. 
[36] Sadak MS, Abdall AM, Abd Elhamid EM, Ezzo MI (2020). Role of melatonin in improving growth, yield quantity and quality of Moringa oleifera L. plant under drought stress. Bulletin of the National Research Centre 44(1):113.

[37] Mihailović N, Lazarević M, Dželetović Z, Vučković M, Đurđević M (1997). Chlorophyllase activity in wheat, Triticum aestivum $\mathrm{L}$. leaves during drought and its dependence on the nitrogen ion form applied. Plant Science 129(2):141-146.

[38] Gu S, Dai X, Xu Z, Niu Q, Jiang J, Liu, Y (2021). Molecular, structural and biochemical characterization of a novel recombinant chlorophyllase from cyanobacterium Oscillatoria acuminata PCC 6304. Microbial Cell Factories 20(1):1-12.

[39] Haider MS, Kurjogi MM, Khalil-urRehman M, Pervez T, Songtao T, Fiaz M, Jogaiah S, Wang C, Fang J (2018). Drought stress revealed physiological, biochemical and gene-expressional variations in 'Yoshihime' peach (Prunus Persica L) cultivar. Journal of Plant Interactions 13(1):83-90.

[40] Bidabadi SS, Mahmood M, Baninasab B, Ghobadi C (2012). Influence of salicylic acid on morphological and physiological responses of banana (Musa acuminata cv. 'Berangan', AAA) shoot tips to in vitro water stress induced by polyethylene glycol. Plant Omics Journal 5(1):33-39.

[41] Surendar KK, Devi DD, Ravi I, Jeyakumar P, Velayudham K (2013). Water stress affects plant relative water content, soluble protein, total chlorophyll content and yield of Ratoon Banana. International Journal of Horticulture 3(17):96-103.

[42] Guo YY, Yu HY, Kong DS, Yan F, Zhang YJ (2016). Effects of drought stress on growth and chlorophyll fluorescence of Lycium ruthenicum Murr. seedlings. Photosynthetica 54(4):524-531.

[43] Mafakheri A, Siosemardeh A, Bahramnejad B, Struik PC, Sohrabi Y (2010). Effect of drought stress on yield, proline and chlorophyll content in three chickpea cultivars. Australian Journal of Crop Science 4(8):580-585.

[44] Meena M, Divyanshu K, Kumar S, Swapnil P, Zehra A, Shukla V, Yadav M, Upadhyay RS (2019). Regulation of L-proline biosynthesis, signal transduction, transport, accumulation and its vital role in plants during variable environmental conditions. Heliyon 5(12):e02952.

[45] Hayat S, Hayat Q, Alyemeni MN, Wani AS, Pichtel J, Ahmad A (2012). Role of proline under changing environments: a review. Plant Signaling and Behavior 7(11):1456-1466.

[46] Rejeb BK, Abdelly C, Savouré A (2014). How reactive oxygen species and proline face stress together. Plant Physiology and Biochemistry 80:278-284.

[47] Surendar KK, Devi DD, Ravi I, Jeyakumar P, Velayudham K (2013). Physiological and biochemical behavior in banana cultivars and hybrids under water deficit. African Journal of Agricultural Research 8(31): 4198-4208.

[48] Agrawal L, Gupta S, Mishra SK, Pandey G, Kumar S, Chauhan PS, Chakrabarty D, Nautiyal CS (2016). Elucidation of complex nature of PEG induced drought-stress response in rice root using comparative proteomics approach. Frontiers in Plant Science 7:1466.

[49] Amnan MA, Pua TL, Lau SE, Tan BC, Yamaguchi H, Hitachi K, Tsuchida K, Komatsu S (2021). Osmotic stress in banana is relieved by exogenous nitric oxide. PeerJ. 9:e10879.

[50] Kapoor D, Bhardwaj S, Landi M, Sharma A, Ramakrishnan M, Sharma A (2020). The Impact of drought in plant metabolism: How to exploit tolerance mechanisms to increase crop production. Applied Sciences 10(16):5692.

[51] Ti-da GE, Fang-gong S, Li-ping L, Yin-yan L, Guang-sheng Z (2006). Effects of water stress on the protective enzyme activities and lipid peroxidation in roots and leaves of summer maize. Agricultural Sciences in China 5(4):291-298.

[52] Kumar RR, Karajol K, Naik GR (2011). Plant physiology effect of polyethylene glycol induced water stress on effect of polyethylene glycol induced water stress on physiological and biochemical responses in Pigeonpea (Cajanus cajan L. Millsp). Recent research in Science and Technology 3(1):148-152.

[53] Guo YY, Yu HY, Yang MM, Kong DS, Zhang YJ (2018). Effect of drought stress on lipid peroxidation, osmotic adjustment and antioxidant enzyme activity of leaves and roots of Lycium ruthenicum Murr. seedling. Russian Journal of Plant Physiology 65:244-250.

[54] Gou W, Zheng P, Tian L, Gao M, Zhang L, Akram NA, Ashraf M (2017). Exogenous application of urea and a urease inhibitor improves drought stress tolerance in maize (Zea mays L.). Journal of Plant Research 130(3):599-609.

[55] Iqbal N, Hussain S, Raza MA, Yang CQ, Safdar ME, Brestic M, Aziz A, Hayyat MS, Asghar MA, Wang XC, Zhang J, Yang W, Liu J (2019). Drought tolerance of soybean (Glycine max L. Merr.) by improved photosynthetic characteristics and an efficient antioxidant enzyme activity under a split-root system. Frontiers in Physiology, 10:786.

[56] Anjum NA, Sharma P, Gill SS, Hasanuzzaman M, Khan EA, Kachhap K, Mohamed AA, Thangavel P, Devi GD, Vasudhevan P, Sofo A, Khan NA, Misra AN, Lukatkin AS, Singh HP, Pereira E, Tuteja N (2016). Catalase and ascorbate peroxidase-representative $\mathrm{H}_{2} \mathrm{O}_{2}$ detoxifying heme enzymes in plants. Environmental Science and Pollution Research 23(19):19002-19029.

[57] de Campos, MKF, de Carvalho K, de Souza FS, Marur CJ, Pereira LFP, Filho JCB, Vieira LGE (2011). Drought tolerance and antioxidant enzymatic activity in transgenic "Swingle" citrumelo plants over-accumulating proline. Environmental and Experimental Botany 72(2):242-250.

[58] Caverzan A., Passaia G, Rosa SB, Ribeiro CW, Lazzarotto F, Margis-Pinheiro M (2012). Plant responses to 
stresses: role of ascorbate peroxidase in the antioxidant protection. Genetics and Molecular Biology 35:10111019.

[59] Kitajima SK, Nii H, Kitamura M (2014). Recombinant Stromal APX defective in the unique loop region showed improved tolerance to hydrogen peroxide. Bioscience, Biotechnology, and Biochemistry 74(7):1501-1503. 